\title{
ワンセグ放送向けストリーム認証方式
}

\section{A Stream Authentication Method for One-Seg Broadcasting}

\author{
栗原淳 ${ }^{\dagger}$ 清本 晋 作 $^{\dagger}$ 渡辺 龍 ${ }^{\dagger}$, 正会員 田 中俊 昭
}

Jun Kurihara $^{\dagger}$, Shinsaku Kiyomoto ${ }^{\dagger}$, Ryu $_{\text {Watanabe }}^{\dagger}$ and Toshiaki Tanaka ${ }^{\dagger}$

\begin{abstract}
In this paper, we present an authentication mechanism for ISDB-T broadcast streams, especially a One-Seg broadcast stream, which is suitable for low-power devices. Our method makes it possible to authenticate data streams at a low computational cost. The method requires a small memory for buffering to process the broadcast stream and is resistant to packet-loss. We evaluated the computational cost of our method by computer simulation and theoretical estimation, and we show here that our method achieved good properties for authenticating data streams broadcast through lossy channels, e.g. wireless channels. Furthermore, we developed a mobile phone that can authenticate One-Seg broadcast streams with our method, and we report the effectiveness of our scheme here.
\end{abstract}

キーワード : メッセージ認証, ストリーム伝送, ISDB-T, ワンセグ放送, 地上デジタル放送, ハッシュ連鎖

\section{1. ま え がき}

\section{1 背 景}

現在，安価な放送機材を用いた，放送免許不要の微弱電波 によるワンセグスポット放送が注目を浴びている ${ }^{1)}$.また, 地域を限定したワンセグ放送を，地域情報展開や災害時の緊 急放送に用いる実証実験が行われている ${ }^{2)}$ 。それに伴い, PC の周辺機器として利用可能な, 安価な ISDB-T(Integrated Services Digital Broadcasting - Terrestrial) ${ }^{3)}$ 放送設備な どが発売され始めている．さらに，USB のワンセグ受信機 などを利用して，放送からワンセグ放送ストリームそのも のを抜き出す手法が出回っている.

しかしながら，現状の ISDB-T 規格におけるワンセグ放 送には放送の正当性を保証する機構が一切ない ${ }^{4)}$ 。このよ うな現状では，抜き出された放送ストリームが改ざんされ， 正規の放送局に成りすまして不正放送を行われるという劦 威が，潜在的に存在する.

そこで本論文では, ISDB-T 放送ストリームのデータの 完全性検証により送信元認証を行うことで，信頼度の高い放 送を実現するストリーム認証方式を提案する。ここで「スト リーム認証」とは,「ストリームが正当な送信者からのもので あるか否かを検証すること」を示す，提案方式は，ISDB-T

2008 年, 電子情報通信学会総合大会で発表 ${ }^{18}$ )

2009 年 11 月 16 日受付, 2010 年 7 月 26 日再受付, 2010 年 10 月 14 日 採録

†株式会社 KDDI 研究所

（テ 356-8502 埼玉県ふじみ野市大原 2-1-15, TEL 049-278-7352）

$\dagger$ KDDI R\&D Laboratories, Inc.

(2-1-15, Ohara, Fujimino, Saitama 356-8502, Japan)
放送のうち特にワンセグ放送を対象とし，携帯電話端末な ど低リソース機器向けの高速・軽量なものを実現することを 目的としている．また，提案手法を実際の携帯電話端末に実 装し，提案手法の有効性を実証実験により確認した ${ }^{18) 19) *}$.

\section{2 ストリーム改ざんによる乫威の事例}

不正放送の一例として，BML(Broadcast Markup Language)を利用したフィッシング詐欺が考えられる. BMLは, ワンセグ放送のデータ放送に用いられる技術である。図 1 に示すように，地上デジタル放送の TS(Transport Stream) において，BML コンテンツはDataの TS パケットとして Audio/Video と多重化されている，前述したように，ワン セグ放送を受信し，その放送ストリーム (TS) そのものを 抜き出す $(\mathrm{PC}$ で受信しながら逐次記録する) 手法が出回っ ているこのとき，TS を受信しながら BML コンテンツを 復元し, リンク部分など小規模なものに改ざんを加えてリ アルタイムに置換 (Re-MUX) することは，技術的に可能 である。すなわち図 1 において, Dataの TS パケットの み都合良く書き換えた改ざん TS を, リアルタイムに作成 することが可能である．悪意のある不正者は，BML を改 ざんした放送ストリームを，正規の放送局に成りすまして 不正に放送し，改ざんされたリンクから受信者をフィッシ ングサイトへ誘導することで，フィッシング詐欺を行うこ とができる.

安価な放送機器が登場している現在，改ざんしたストリー ムの再送信は，コスト面を含めて容易に可能である。ワン セグスポット放送やエリアポータル放送が実現されたとき，

\footnotetext{
*端末への実装は第 $\mathbf{5}$ 節にて紹介.
} 
Flow Direction of Transport Stream

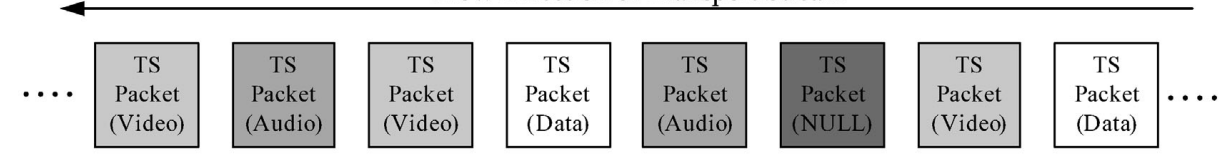

図 1 TS(Transport Stream) 概略図

Schematic draw of TS(Transport Stream).

\begin{tabular}{c|c}
\multicolumn{2}{c}{$\begin{array}{c}\text { 表 } 1 \text { 略語一覧 } \\
\text { Abbreviations. }\end{array}$} \\
\hline \hline ISDB-T & $\begin{array}{c}\text { Integrated Services Digital } \\
\text { Broadcasting - Terrestrial }\end{array}$ \\
\hline TS & Transport Stream \\
\hline PID & Packet ID \\
\hline NIT & Network Information Table \\
\hline PMT & Program Map Table \\
\hline CC & Continuity Counter \\
\hline VP & Verification Packet \\
\hline LB & Lower Block \\
\hline UB & Upper Block \\
\hline MHV & Master Hash Value \\
\hline
\end{tabular}

不正放送は現実的な劦威となる。

また，ワンセグ放送は災害時の緊急放送としての利用も 検討されている.このとき, 音声・映像・データ放送すべて または一部を改ざんした不正放送を送信し，既存放送局を 騙って災害時に誤情報を流布するデマゴーグの出現も，充 分に考えうる劦威である．災害時の緊急放送など著しく公 共性が高い放送では，映像・音声・デー夕放送すべてが正 しい送信元から放送されたことが高度に保証 (送信元認証) されることが必要である.

\section{3 論文の構成}

本論文は以下のように構成される。：第 2 節において, ワンセグ放送に認証機能を付与する際の課題と，ストリー ミング伝送の認証技術の既存研究について述べる. 第 3 節 において，提案するストリーム認証方式を示す．第 4 節に おいて, 提案方式のパケットロス耐性評価および処理効率 を示し，前節で述べた課題に関する考察を行う．第 5 節で は，提案方式の実装例の紹介を行う。最後に第 6 節におい て結論を述べる。また，本論文全体において表 1 に示寸略 語を使用する。

\section{2. 関連研究とその課題}

\section{1 解決すべき課題}

地上デジタル放送は，生放送などに対応するため，送信 側においてはリアルタイムのストリーミング伝送を必要と する．また，無線通信路を利用するため，受信状況によっ てはパケットロスが多く発生する。ささら，ワンセグ放送 などの携帯機器向け放送では, 計算能力やバッファサイズ が小さく制限された携帯電話などの低リソース機器が受信 機の中心となる。したがって，以下の課題を考慮した，低 リソース機器に対して効果的なストリーム認証方式を検討 する必要がある.
課題 (a) 無線伝送路におけるパケットロス対策.

課題 (b) 署名生成の際の送信側の遅延低減.

課題 (c) 署名検証の際の受信側のバッファサイズ縮小, 遅 延・処理負荷低減.

さらに，地上デジタル放送は既にサービスが開始されてい るため，既存の放送サービスや端末との整合性を考慮し，以 下の課題を考慮しなければならない。

課題 (d) 認証機能に対応した放送ストリームが，既存の 受信端末に影響を与えないこと。

\section{2 関連研究}

地上デジタル放送ストリームの送信元認証方式は，筆者 らの知る限り提案されていない，そこで本節では，一般的 なネットワークストリーミング伝送を対象とした認証方式 の既存研究について述べる.

最も基本的なストリーミング伝送の認証方式としては, 以下の二つの方式が挙げられる.

（1）一般的なデータ転送と同様に，コンテンツ情報全 体に電子署名を行う手法.

（2）送信されるパケットごとに送信者の電子署名を付 与する手法.

前者の手法は，すべてのデータを受信するまでコンテンツ の正当性を検証することができず，後者の手法は，署名の 生成・検証の計算量的負荷が大きいという課題がある。これ らの課題の解決策として, Gennaro らは Chain 方式 ${ }^{5)}$ と 呼ばれる手法を提案している. Chain 方式では，各パケッ トが一つ後のパケットのハッシュ值を持ち, 先頭パケット のみに署名を付与する。一般的に，ハッシュ值の生成処理 は，公開鍵による署名生成処理よりも，100 倍から 1,000 倍高速に動作する．したがって，先頭パケットに対しての み署名の検証を行い, 後続のパケットに対してはハッシュ 值の計算のみで認証が行える Chain 方式は，非常に効率的 である．しかしながら，Chain 方式を施したストリーム内 部にパケットロスが発生した場合，ハッシュ值の連続しな い部分が生じるため, 認証が途切れてしまうという久点が ある、そのため, パケットロスの発生を考慮しなければな らない伝送路において，パケットロス耐性のない Chain 方 式を用いることは困難である.

このような背景を受け，パケットロス耐性を有する，効 率的なストリームの認証方式がいくつか提案された.

Wong らによるWLtree 方式 ${ }^{6)}$ では, 複数のパケットか らハッシュ值の tree 構造 7) 生成し, tree のルートのハッ シュ值に対し署名を生成する.このため, 1 回の署名の検証 
処理で複数パケットの認証が可能であり, 効率的に動作す る.しかし，グループ化するハッシュ值の tree が増大する につれ, 付加するハッシュ值の数も増大寸る. さらに, tree を生成するために用いるパケットバッファが大きくなるた め, 送信時の遅延が大きく, 受信機におけるバッファサイ ズも大きくとる必要があるという欠点がある.

また，再帰的なハッシュ連鎖によりバーストパケットロス 耐性を備えた, Augmented Chain 方式 ${ }^{8)}$ というストリーム 認証方式が, Golleらによって提案されている. Augmented Chain 方式は，効率的な動作を可能とするが，ランダムパ ケットロスへの耐性を有しないという問題がある.

一方, Perrig らによって提案された EMSS 方式 ${ }^{9)}$ は, 各パケットに過去の複数のパケットのハッシュ值を付与し, ハッシュ連鎖を生成する。同様に，田中らのストリーム認 証方式 ${ }^{10) 11)}$ も，2 階層のハッシュ連鎖を用い，一定数のパ ケットをバッファリングして処理することで，バーストパ ケットロスとランダムパケットロスに対応している. EMSS 方式, 田中らのストリーム認証方式のどちらも, 効率的な 処理とパケットロスへの耐性を有しているが，受信機にお いてパケットのバッファサイズを大きくとる必要があり, 低 リソース機器向けの認証方式ではないと言える.

上田らは, IP 電話への適用を想定し，バースト・ランダ ムパケットロスへ耐性を持つ, 低リソースデバイス向けの ストリーム認証方式 ${ }^{12)}$ を提案している. さらに宇田らは, 固定長パケットに対応し, 署名間隔のシームレスな変更に 適用可能な, IP 電話向けストリーム認証方式 ${ }^{13)}$ を提案し ている.これらの方式は, 話者双方の認証が可能であり, 認 証のためのバッファサイズが小さい効率的な手法である.

上記で述べたすべての既存研究は, ストリーミングコン テンツのパケットにハッシュ值や電子署名を埋め込む形で 実現される、そのため, これらの方式を既存の地上デジタ ル放送に適用するには, 規定された映像・音声・データ放 送などのメディアパケットの構成を, 大きく変える必要が ある、したがって, 前述した既存手法では, 現状の地上デ ジタル放送サービスに認証機能を追加して実現することは 不可能である。

\section{3. 提 案 方 式}

本論文では, ISDB-T 地上デジタル放送, 特にワンセグ 放送向けのストリーム認証方式を新たに提案する.まず，地 上デジタル放送において認証するストリームを以下のよう に規定する.

・認証の対象とするストリームは, MPEG2-TS 規格の TS(Transport Stream) とする.

• TS は, 固定長 (188byte) の TS パケットによって構成 される.

・ある確率で受信機においてパケットロスが生じる.

・TS における TS パケットの順序逆転は, デジタル放送 の性質上, 生じない.
ワンセグ放送では，映像・音声は動画像圧縮符号化された 後, データ放送とともに, TS パケットへ分割・多重化され MPEG2-TS 規格のストリーム (TS) を構成する (図 1).こ のため, 提案方式では, これら TSパケットを認証対象とし ている.また, ISDB-T の規格では, 外符号として ReedSolomon 符号 ${ }^{14)}$ をパケットごとに適用し，さらに内符号 の畳み込み符号をビットストリームに適用している.この ため，受信機において復元された TS では，パケットロス は生じても, パケットの順序逆転は発生しない.

上記の規定を踏まえて，ストリームへの認証機能の付与 方式を提案する。提案方式では，ハッシュおよび署名情報を 含む検証パケット (Verification Packet,VP) を新規の PID を用いて定義し，通常のワンセグ放送のストリームに挿入 することで，認証機能を実現する.

ワンセグ放送運用規定 ${ }^{4)}$ に执いて，PIDフィルタを有す るワンセグ受信端末がレファレンスモデルとして示されて いる.このレファレンスモデルを反映し，受信端末は開発 される。このため, 通常のワンセグ受信端末では, 固定值 のPID を有するパケットか, PMTにより規定された PID を有するパケット以外の受信パケットは, PID フィルタに より取り除かれる。すなわち, 認証機能に非対応な従来端 末では，PMTに記載されない PID を有する VP は，受信 時に不要なパケットとして破棄され，正常な再生に支障を きたさない.

以降，認証機能の実現方式について述べる.

\section{1 ハッシュ生成方式}

通常, 電子署名を用いたメッセージ認証 ${ }^{15)}$ では, 対象と なるデータすべてに対してハッシュを生成し，署名を施す. 一方，提案方式では，パケットサンプリングによって認証 対象 (ハッシュ生成対象) パケットを削減し，処理負荷の削 減を行う。さらに, 階層型ハッシュ生成方式を用いて, 送 信側バッファサイズの縮小を行う.

パケットサンプリング: デジタル放送におけるコンテンツ 改ざん等の対策のために, 改ざんされたコンテンツの再生 を防止することを考える，このとき，以下の点のどちらか が実現されることが必要である.

（1）認証対象パケットが改ざんされた場合, 改ざんさ れたことを検知可能.

（2）認証対象パケット以外が改ざんされた場合であっ ても, 改ざんされたコンテンツを正常に再生するこ とは不可能.

まず，(1)の点を考慮する. 改ざんコンテンツの検知, 改 ざんコンテンツの再生防止をするために, ISDB-T のワン セグ放送ストリーム (TS) では，認証す心゙きパケットは以 下となる*。

・再生されるコンテンツそのものであり，直接の改ざん

*ワンセグ放送にはPAT(Program Association Table) パケットは含ま れない.

(143) 1923 


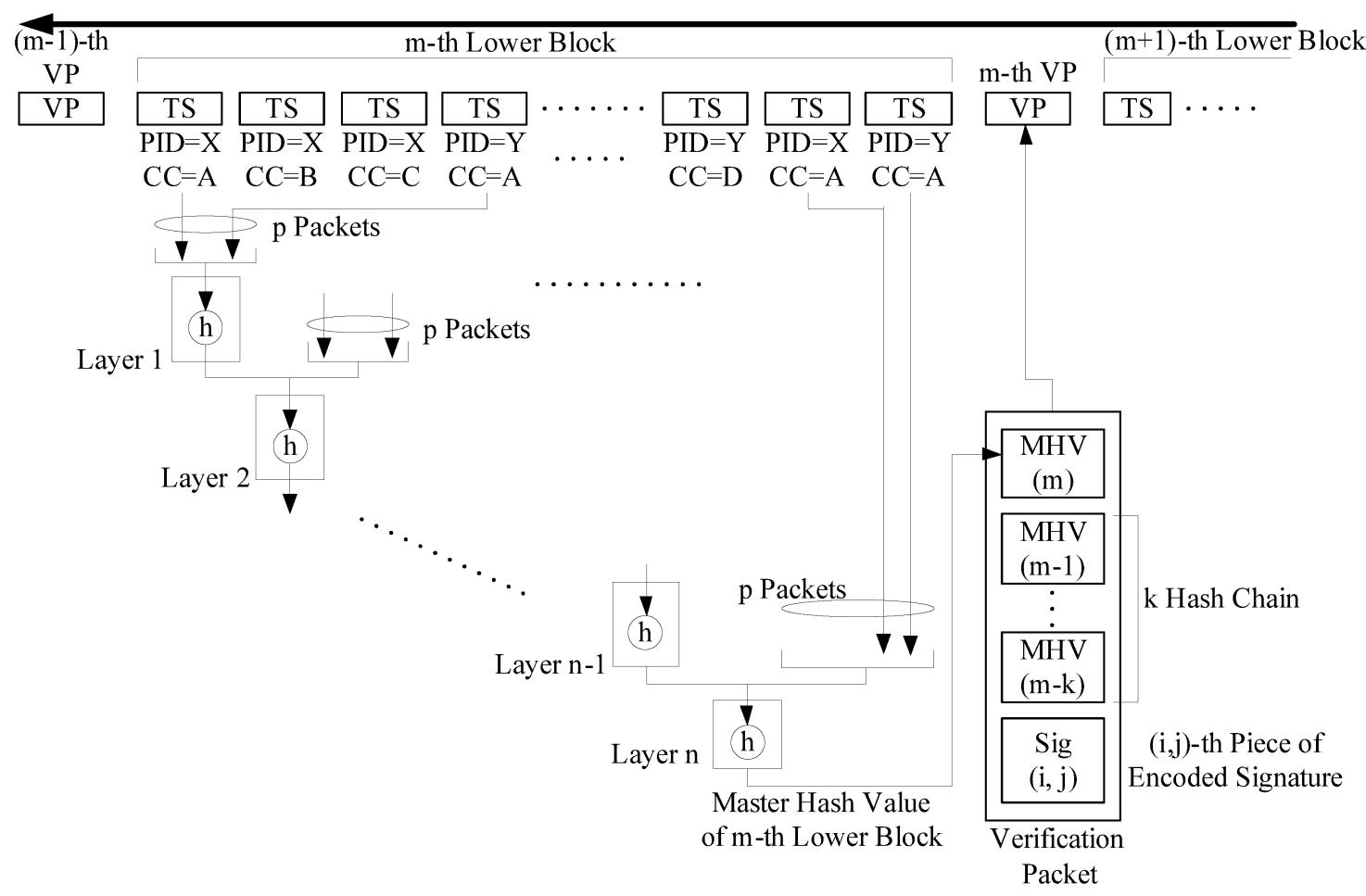

図 2 階層型ハッシュ, ハッシュ連鎖, 検証パケットの生成フロー

Generating flow of hierarchical hash, hash chain and verification packet.

対象となるAudio/Video/Dataなどのメディアのパケット.

・チャネル番号情報などが含まれる NIT(Network Information Table).

・メディアパケットの PID が記載される PMT(Program Map Table).

次に，(2) の点を考慮する. MPEG2-TS では, Audio/Video/Data などそれぞれのメディアを正常に再生す るために, TS 中の同一 PID の TS パケットを, 連続し て受信する必要がある。このため, 正常に再生可能な場合 に確実に認証されれば良いとすれば，ストリーム中の $\mathrm{Au}$ dio/Video/Data のメディアパケットを連続してすべて認 証の対象 (ハッシュ值を生成する対象) とする必要はない. したがって，メディアの PID を持つTS パケットについて, 一定周期でサンプリングして認証対象とする。このとき, 認証対象としたパケット以外のパケットの改ざんは，検知 することができない. しかしながら，そのような改ざんは， 連続するメディアパケット中の認証対象パケットを除外し て行う必要がある.このため, 改ざんコンテンツのメディ アパケットと, 改ざん前の (認証対象) メディアパケットが 一つのストリーム中で瓦い違いに混在し，再生するための 整合性がとれなくなる.したがってこの場合は, メディア 自体が正常に再生できなくなるため, 改ざんコンテンツを 受信者に視聴させることは不可能である.

以上のことより, 提案手法では以下の種類の TS パケッ トをハッシュ值生成の対象とする.

- NIT の全パケット

- PMTの全パケット
•Audio/Video/Data などのメディアについて, CC (Continuity Counter) 值が規定值のパケット

$\mathrm{CC}$ 值は, TS パケットヘッダ内部に 4 ビットの值で記述さ れ，0-15 の值でパケット順ごとにループカウントを行う. したがって，メディアのパケットを CC の值でサンプリン グすることにより，認証対象とするパケットを従来方式の 最大 $1 / 16$ まで削減することが可能となる.

階層型ハッシュ生成: 提案方式では, 認証対象としてサン プリングした TS パケットのハッシュ值を計算し，さらに 署名を生成する. 図 2 に, ハッシュ生成方式を示す.

ハッシュ值の生成方式には，階層型のハッシュ生成方式 を用いる. TS の先頭より認証対象の TS パケット $p$ 個を 1 ブロックとし，1ブロック分の TS パケットを連結してハッ シュ值を計算する. 次に, 図 2 に示すように, 生成したハッ シュ值と次の 1 ブロック分の TS パケットを結合し，新規 の階層のハッシュ值を生成する.ここで, 連続 $n$ ブロック ( $n$ 階層) を一つの「下位ブロック (Lower Block, LB)」と 定義し, $n$ 階層目のハッシュを当該 LB のマスタハッシュ 值 (Master Hash Value, MHV) とする.

\section{2 ハッシュ連鎖, 署名格納方式}

生成した MHVは，新たに構成される VP 内部に格納さ れる.さらにこの MHVのコピーを, 後続の複数の VPにも 格納することでハッシュ連鎖を構成し，ハッシュのパケット ロス対策を実現した。図 2 では， $k$ 個前までの LBの MHV も，当該 $\mathrm{LB} の \mathrm{MHV}$ と同時に VP 一格納している. 図 3 に, $k+1$ 個の VPにまたがるハッシュ連鎖の構成図の詳 


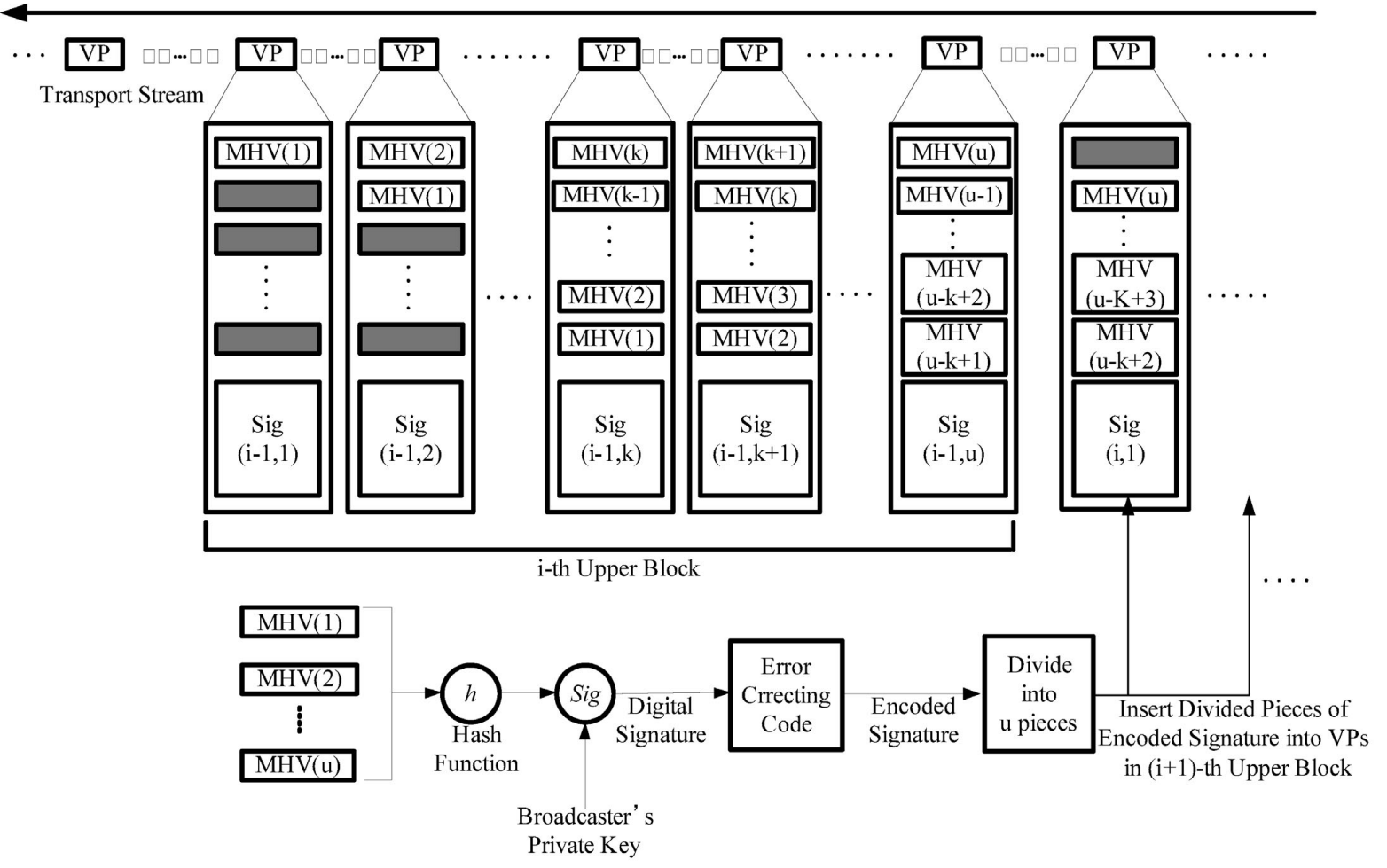

図 3 上位ブロック構成, ハッシュ連鎖・分割署名生成フロー

Structure of upper blocks, and generating flow of hash chain and divided codeword.

細を示す。ハッシュ連鎖は, Perrig $5^{9)}$ ，田中ら ${ }^{10) 11)}$ の 手法でも用いられている. Perrig・田中らの手法9) 11) とは 異なり, 我々の提案方式では既存の受信端末に影響を与え ることを避けるため, メディアパケットにハッシュ連鎖を 付与せず，新規に定義した VPのみにハッシュ連鎖を格納 している.

提案方式では，MHVと同時に署名を VP へ格納する．ま ず，連続する $u$ 個の LB を，一つの「上位ブロック (Upper Block, UB)」と定義する. 提案方式では，一つのUBにつ いて一つの署名を生成する. 図 3 に示すように, 署名の生 成・VPへの格納は, 以下の手順で行われる.

（1） UB 内で生成された $u$ 個の MHV の連結に対し, 秘密鍵によって当該 UB の署名を生成する.

（2）生成した署名を $v$ 個に分割し，符号化率 $v / u$ の誤 り (消失) 訂正符号化を行うことで， $u$ 個の符号化署 名の断片を生成する.

（3）符号化署名の断片は, 当該 UB の次の UB 内の $\operatorname{VP}(u$ 個 $)$ にひとつずつ格納される.

図 3 では, $i$ 番目の UB $の ~ k$ 番目 $(k=1, \ldots, u)$ のB の $\mathrm{VP}$ に, $(i-1)$ 番目の UB で生成された符号化署名の $k$ 番 目の断片を格納している. 当該 UB 内の LB 数の具体的な 值は $u$ に等しい.

\section{3 検証処理}

受信機では，送信側と同じ処理により MHVを生成し， VP 内部の MHV との比較検証を行う.さらに, 取得した VP から当該UBに対する分割符号化署名を取得, 署名を復 号する.この後, MHVの連結に対して生成したハッシュ,
署名の検証用の公開鍵 $($ 検証鍵 $)$ を用いて，復号した署名の 検証を行う.

また，受信しているTS 中にVP が観測できない場合，送 信元の認証を行うことはできない，そのため実運用におい ては，一定時間 VP が到来しない場合に，「署名が存在しな い放送である旨」を視聴者に通知することが必要である。

\section{4. 方 式 評 価}

本節では，ワンセグ放送を想定した計算機シミュレーショ ンを行い，提案方式のパケットロス耐性を評価する。また， 処理負荷を見積もるため，八ッシュ計算回数・署名生成/検 証処理回数の理論值における評価を行う。最後に，パケッ トロス耐性評価，提案方式の処理効率の評価を元に，提案 方式に関する考察を行う。

\section{1 評価環境}

表 2 に計算機シミュレーションにおける共通パラメータ を示す．提案方式のパケットロス耐性評価では，共通パラ メータを基本とし，一部のパラメータを変化させた場合の パケットロス耐性の変化, 署名検証可能回数の平均を評価 する.

シミュレーションに用いる TSにおいて, メディア TS パケ ットのビットレートは, 標準的なワンセグ放送のパラメータ を想定し，Video/Audio/Dataそれぞれを 128/64/60kbps と設定した。メディア TS パケットに加え， NIT・PMT・ NULL 等のメディア以外の TS パケットすべてを含んだ総 ビットレートも，ワンセグ放送の規格である $416 \mathrm{kbps}$ と した.

(145) 1925 
表 2 計算機シミュレーションにおける共通パラメータ Common parameters in computer simulation.

\begin{tabular}{|c|c|}
\hline $\mathrm{TS}$ パラメータ & $\begin{array}{c}\text { Video: } 128 \mathrm{kbps} \\
\text { Audio: } 64 \mathrm{kbps} \\
\text { Data: } 60 \mathrm{kbps} \\
\text { 総ビットレート (含 NULL): } 416 \mathrm{kbps}\end{array}$ \\
\hline 標本パラメータ & $\begin{array}{r}\text { 総パケット数 (含 NULL): 20,870,610 個 } \\
\text { (約 } 1258 \text { 分) } \\
\text { 署名検証試行回数: } 12840 \text { 回 }\end{array}$ \\
\hline サンプリング対象パケット & $\begin{array}{c}\text { NIT,PMT: 全パケット } \\
\text { Audio/Video/Data: } \mathrm{CC}=0 \mathrm{x} 0001\end{array}$ \\
\hline $\begin{array}{l}\text { ハッシュ生成アルゴリズム } \\
\text { ハッシュ階層 } n \\
\text { ハッシュ生成パケット数 } p\end{array}$ & $\begin{array}{c}\text { MD5 (128 ビット) } \\
8 \\
1\end{array}$ \\
\hline チェーン数 $k$ & 4 \\
\hline $\begin{array}{c}\text { 署名方式 } \\
\text { 署名の誤り訂正符号化方式 } \\
\text { 誤り訂正符号の符号化率 } \\
\text { 分割符号化署名の長さ }\end{array}$ & $\begin{array}{c}2048 \text { ビット RSA } \\
\text { 繰り返し符号 } \\
1 / 4 \\
512 \mathrm{bits}\end{array}$ \\
\hline パケットロスモデル & ランダムパケットロス \\
\hline
\end{tabular}

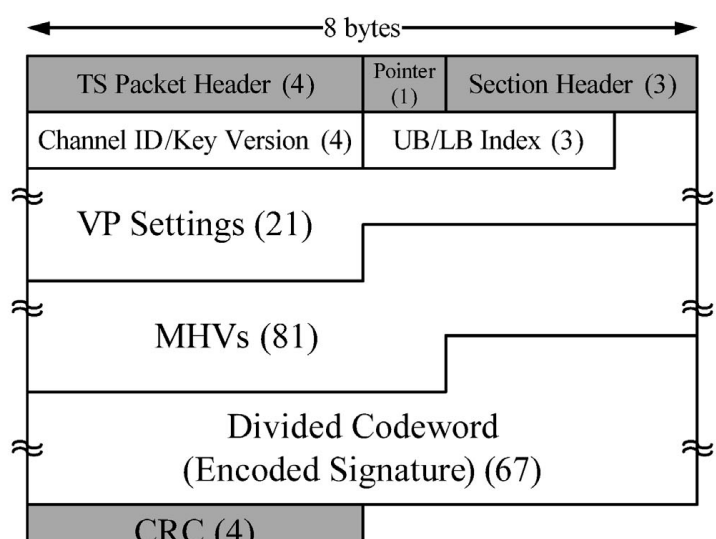

図 4 計算機シミュレーションにおろる検証パケット (VP) の 構成

Structure of verification packet (VP) in computer simulation.

共通パラメータにおけるサンプリング対象には，NIT • PMT の全パケット, Audio/Video/Data の CC 值 0 のパ ケットを用いた。本論文では，0-15の 16 值をとる CC 值のうち, サンプリング対象とする CC 值の個数を $m$ $(1 \leqq m \leqq 16)$ とし, サンプリング頻度のパラメータと して用いる. また，ハッシュ生成アルゴリズムには 128 ビッ トのハッシュを生成し，軽量に動作する MD5 を用いた。 ハッシュ階層 $n$ は 8 とし, 1 回のハッシュ生成時に取得する パケット数は 1 とした. ハッシュ連鎖の長さ $k$ は 4 とした. 受信機に低リソース機器を想定するとき，署名の検証処 理は軽量であることが望ましい，そのため，署名生成アル ゴリズムにはECDSA 署名など様々な方式が考えられるが, その中でも携帯電話端末において高速・軽量に署名検証可 能な RSA 署名 ${ }^{16)}$ を用いた。鍵長は 2048 ビットとした.

同様に，署名を符号化する誤り訂正符号も，受信機側の復 号処理が軽量であることが望ましい. よって, 誤り訂正符号 には，単純・軽量な復号処理で動作する符号化率 $v / u=1 / 4$ の繰り返し符号 (繰り返し数 $r=4=u / v)$ を使用した. 繰 り返し符号とは，符号化されるデータそのもののコピーが
パリティとして付加される誤り訂正符号である. 繰り返し 数が $r$ であれば，符号化されるデータの $r$ 個のコピーの連 結が, 符号語となる。復号処理は, 久落したメッセージの ブロックを，単純にパリティから補填することで実現され るため, 非常に高速に動作する. 8192 ビットとなる符号化 された署名は， 512 ビットごとに 16 個に分割される．結果 として,一つの UB 内に存在する LB の数 (MHV の数) $u$ は 16 となる。

図 4 に，計算機シミュレーションに用いた VP の構成を 示す. 各フィールド名に付く括弧の中の值は，当該のフィー ルドのバイト数である. Channel ID/Key Versionフィー ルドには，放送局の ID および署名の検証鍵のバージョンを 記述する. UB/LB Index フィールドには, 当該 VP の存在 するUBのインデックス番号, MHVを生成した LB のイン デックス番号を記述する. VP Settings フィールドには, $p$, $n$, サンプリング対象 CC 值など， MHV を生成するため のパラメータを記述する. MHVs フィールドには, MHV, およびハッシュ連鎖によりコピーされた過去の MHVが格 納される. Divided Codeword フィールドには，分割され た符号化署名の断片が格納される．各フィールドは，長さ を調節するためのパディング，スタッフィングが含まれる. パケットロス耐性評価における計算機シミュレーション では，VPを挿入した TS ついて，TS 中のパケットを 確率的に NULL パケットと置換して, 擬似的にパケット ロスを発生させる. ISDB-T 規格では，TS 符号化・変 調して伝送する際に, 複数のインターリーバを利用してい る ${ }^{17)}$ 。これにより, 伝送路 (物理レイヤ) で生じた小規模 なバーストェラーは，TS レイヤではランダムパケットロ スとして観測される。一方，インターリーブ範囲を超過す るような大規模なバーストエラーは，TS レイヤでもバー ストパケットロスとなり，そもそも受信不可能な状態とみ なせる，放送の信頼性確保のためには，受信可能な放送に ついての認証可否を検討する必要がある。そのため，本実 験では，パケットロスモデルとして，パケットロスレート (Packet-Loss Rate, PLR) に基づいたランダムパケットロ スを用いた。

\section{2 パケットロス耐性評価}

以下に，パケットロス耐性の評価結果を示す.

$\mathrm{CC}$ 值によるサンプリング頻度： 図 5 に，認証対象とする パケットのサンプリング頻度を変化させた場合の，パケッ トロス耐性に与える影響を表すグラフを示す，横軸は，TS 中の PLR である. 縦軸は，ランダムパケットロスを挿入 したTSにおける署名検証試行回数に対する，署名検証の 成功回数の平均割合である.また, 図 5 では, パラメータ $m$ に加えて, サンプリング対象とした CC 值の具体的な值 を 4 桁の 16 進数を用いて示している. 16 進数の 1 となっ ているビットが，サンプリング対象の CC 值に対応する. 例えば，0x0101 であれば CC 值 0 および 8 のパケットが, 


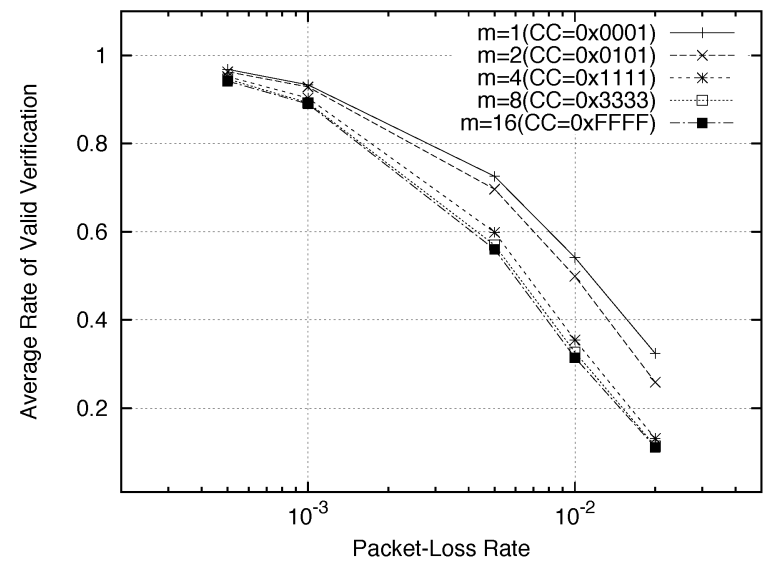

図 5 認証対象パケットのサンプリングレートによるパケットロス而性 Packet-loss registance for sampling rate of verified packets.

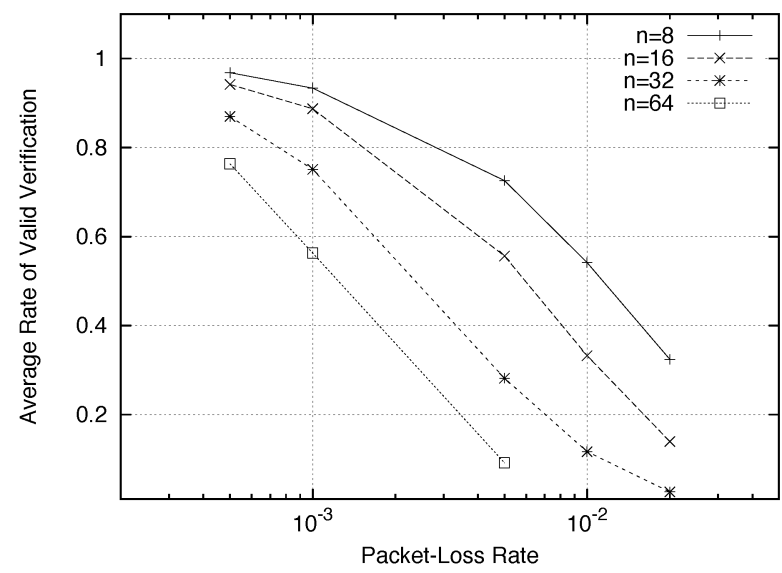

図 7 ハッシュ階層数 $n$ によるパケットロス耐性 Packet-loss registance for the number of hash hierarchy.

0xFFFF であればすべてのパケットがサンプリング対象と なる．本グラフにより，パケットロス耐性とサンプリング 頻度の依存関係の大きさが明らかとなる。

図 5 では，個々の曲線に大きな違いはなく，全体に良好 な結果が得られているが，サンプリング頻度が大きくなる ほどパケットロス耐性が悪化する傾向がある．PLRを一定 としたとき，サンプリング頻度が大きくなれば，サンプリ ングした TS パケット中で観測されるパケットロスの頻度 も増加する．署名の検証が成功するか否かは，サンプリン グした TS パケット中のパケットロスに依存する。このた め, 提案方式ではサンプリング頻度が小さいほど良好な結 果を得ていると考えられる。

1 回のハッシュ対象パケット数 $p:$ 図 6 に, ハッシュを 生成するために連結する TS パケット数 $p$ を変化させた場 合の，パケットロス耐性に与える影響を表すグラフを示す. 図 5 同様に，横軸はPLR，縦軸は正常な署名検証の平均 レートである。

図 6 では，pが小さいほど良好な結果を得ていることが わかる。これは， $p$ 以外のパラメータ $(n$ および $u)$ が共通

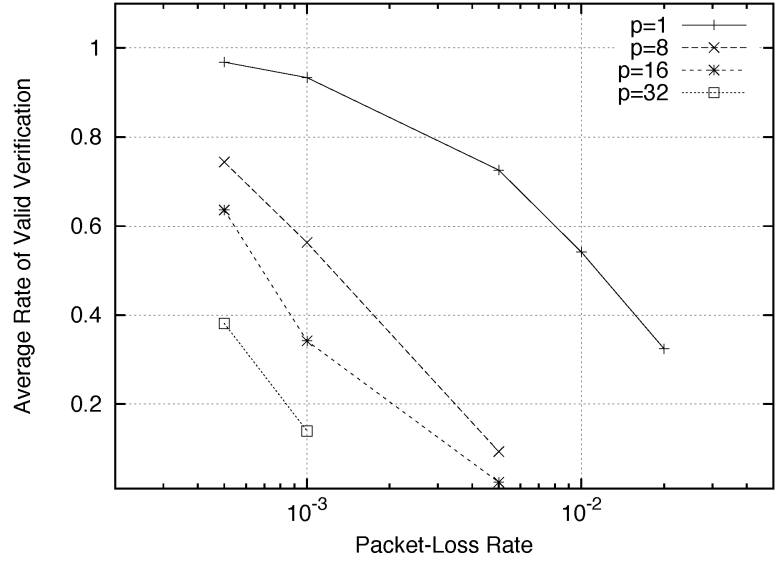

図 61 回のハッシュ生成時に用いるパケット数 $p$ による パケットロス耐性

Packet-loss registance for the number of one-time hashed packets, $p$.

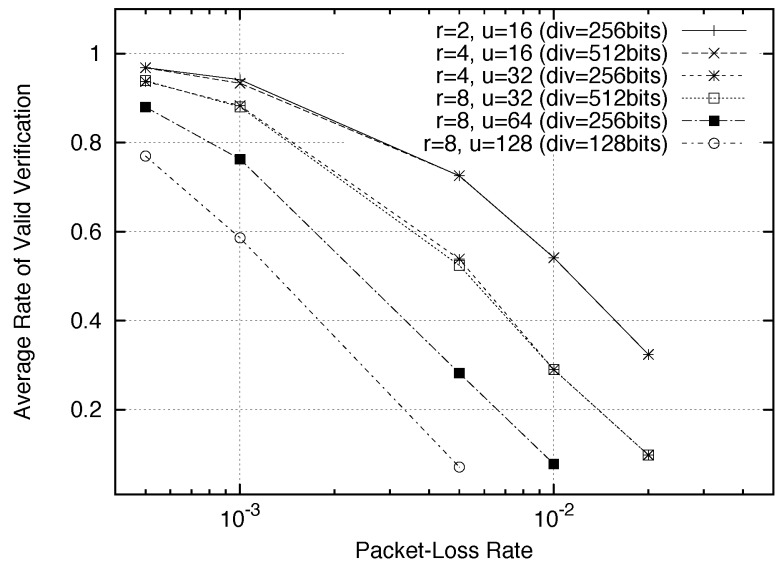

図 8 符号化率 (繰り返し数 $r$ ), 分割数 $u$ によるパケットロス耐性 Packet-loss registance for code rate (Repetition number $r$ ) and Division number $u$.

であるため, $p$ が大きくなるほど一つの LB・UB の持続時 間が長くなる。このため，一つのブロック内で認証対象パ ケットの欠落する確率が大きくなることで，MHVの生成・ 検証処理の失敗確率が大きくなることに起因していると考 えられる。

ハッシュ階層数 $n:$ 図 7 に, ハッシュ階層の深さ $n$ を変 化させた場合の，パケットロス耐性に与える影響を表すグ ラフを示す. 図 5 同様に, 横軸はPLR, 縦軸は正常な署名 検証の平均レートである。

図 7 では，ハッシュ階層が浅いほど良好な結果を得てい ることがわかる。これは，図 6 同様に， $n$ が大きくなるほ どに一つの LB・UB の持続時間が長くなり, 一つのブロッ ク内で認証対象パケットの欠落する確率が大きくなったた め, MHVの生成・検証処理の失敗確率が大きくなること に起因していると考えられる。

署名の符号化率 $1 / r$ および分割数 $u$ ：図 8 に，署名の符 号化率 $v / u=1 / r($ 繰り返し符号の繰り返し数 $r)$, および 符号化署名の分割数 $u$ を変化させた場合の，パケットロス 
耐性に与える影響を表すグラフを示す. 図 5 同様に，横軸 はPLR, 縦軸は正常な署名検証の平均レートである.

このとき, 提案方式の構成より, 符号化署名の分割数 $u$ は一つの UB 内に存在する LB の数 (MHVの数) に等しい. また，署名長は 2048 ビットであるため，分割された符号 化署名の個々の断片は, $2048 r / u$ ビットとなる. 図 8 では, 断片のビットサイズを「div」として表記している.

図 8 では, 繰り返し符号の繰り返し数 $r$ および分割数 $u$ の組合せに, $(r, u)=(4,16)$ および $(2,16)$ を与えた結果 がほぼ同一となり, 最も良好な傾向を示している.さらに, $(r, u)=(4,32)$ での結果と $(r, u)=(8,32)$ で行った結果 も，ほぼ同一の曲線を描くことが示されている。これらの ことより, 誤り訂正符号に繰り返し符号を用いた場合には, 繰り返し数 $r$ はほとんどパケットロス耐性に影響しないが, 分割数 $u($ 一つの UB 内部の LB の数 $u)$ は大きく影響する ことがわかる。

サンプリング頻度等を一定として $u$ を大きくすることで, 一つの UB の持続時間は長くなる. このとき, 各ブロック 内で認証対象パケットの久落する確率が大きくなり, $\mathrm{MHV}$ の生成・検証処理の失敗確率が増大する。一方, VP の到 来頻度は, 認証対象パケットの到来頻度よりも非常に低い. よって，PLRを一定としたときにVP が欠落する確率は, 認証対象パケットが久落する確率より非常に低くなる。こ れらのことから, VP の久落 (署名の久落) への耐性を決定 する $r$ よりも, $u$ が署名検証成功確率に大きく影響したと 考えられる.

\section{3 処理負荷}

本節では, 提案方式の処理効率に関する, 理論的な解析 を行う。

標準的なワンセグ放送を想定し，Audio/Video/Data そ れぞれのビットレートを 128/64/60 kbps とする.また ARIB 規定の標準的な值より, $\mathrm{PMT} / \mathrm{NIT}$ の再送周期は, それぞれ 200/1000 msec とする ${ }^{17)}$. すなわち, PMT/NIT の伝送容量を，それぞれ 7.52/1.504 kbps と見積もる. 提案 方式では, CC 值を元にAudio/Video/DataのTS パケット のサンプリングを行い, 認証対象とする. サンプリング対象 $\mathrm{CC}$ 值の数を示すパラメータ $m$ を用いると, 認証対象とする Audio/Video/Dataの TS パケットの疑似ビットレートは, それぞれ $8 \mathrm{~m} / 4 \mathrm{~m} / 3.75 \mathrm{~m} \mathrm{kbps}$ となる. すなわち, メディア TS パケット全体における認証対象となる TS パケットの疑 似ビットレートは， $15.75 \mathrm{~m} \mathrm{kbps}$ と見積もることができる. また, $\mathrm{PMT} / \mathrm{NIT}$ の合計ビットレートは, $9.024 \mathrm{kbps}$ と見 積もることができる. したがって $(15.75 m+9.024) \mathrm{kbps}$ の擬似ストリームが, 認証対象ストリームと考えることが できる.ここで, 便宜上 $f(m)=15.75 m+9.024$ とおく. 認証対象ストリームのビットレート $(\mathrm{kbps})$ をパケット レートに換算する. 認証対象ストリームのパケットレート を $g(m)$ と表わすと, TS パケットは 1 パケット 1504 ビッ ト (188 バイト) であるため, $g(m)$ は以下となる.

$$
g(m)=\frac{10^{3} \cdot f(m)}{1504}(\mathrm{pps}) .
$$

ここで, ppsは packet per second を意味する. 上式より， 到来 TS パケット $p$ 個ずつからハッシュ值を生成するとき, 1 秒間に平均 $\frac{g(m)}{p}$ 回のハッシュ計算処理が実行されると 見積もることができる，さらにこの場合，ハッシュ階層の 深さを $n$ ととすれば, $\frac{n p}{g(m)}$ 秒に 1 回, VP を TS へ挿入 し， LB が構成されることとなる．同様に，UBを $u$ 個の LB で構成し，符号化署名を $u$ 個に分割してVPに格納す るとき, $\frac{n p u}{g(m)}$ 秒に 1 回, RSA 署名の生成 (受信機側では 検証) 処理・署名の符号化 (受信機側では復号) が行われる.

次に, 受信機側における, MHV 生成時の必要バッファ サイズを見積もる.八ッシュ階層の第 $t$ 階層 $(2 \leqq t \leqq n)$ では, $t-1$ 階層目のハッシュ值と $p$ 個の TS パケットを連 結し, ハッシュ值を生成する。次の階層に移動する際, TS パケットを保存していたバッファは解放されるため, MHV の生成には $(1504 p+h)$ ビットのバッファが必要となる.こ のとき, $h$ はハッシュのビット長を表す.

\section{4 考 察}

本節では，第 4.2 節で行ったパケットロス耐性評価と， 第 4.3 節で行った処理効率の見積もりを元に, 提案方式と 他方式の比較・考察を行う。しかし, 第 2.2 節に述べたよ うに, 既存の IP ストリーミング伝送向けの関連研究は, 地 上デジタル放送の TS そそのまま適用することができない. すなわち，提案手法と同条件での比較は不可能である。よつ て，ここでは放送ストリームを認証する方式として一般的 な手法を挙げ，提案方式と比較することとする.

最も単純な手法としては, 認証対象とするパケットすべ てをバッファし，ハッシュ・署名を生成して圥長性なしで TS に埋め込んで送信する手法が考えられる.ここで, 提案 方式と同じ状況を想定し，提案方式における一つの LB 内 の Audio/Video/Data およびNIT/PMTす心゙てのパケッ トを, サンプリングなしで認証対象とし，ハッシュ階層を 用いずに MHV を生成することを考える，さらに，一つの $\mathrm{UB}(u$ 個の LB) について生成した $u$ 個の MHVを連結し, $\mathrm{MHV}$ の連結のハッシュ值について署名を生成することと する。この際，生成した署名は，UBの最後に埋め込まれ て送信されることと仮定する。

提案方式に関しては，第 4.3 節より，

-ハッシュ処理 : $\frac{g(m)}{p}$ times/sec

- 署名生成 (検証) : $\frac{g(m)}{n p u}$ times/sec

- VP 挿入間隔 : $\frac{n p}{g(m)} \mathrm{sec}$

- MHV 生成時の TS パケットバッファ: $(1504 p+h)$ bits が得られる. これらより, $m, n, p, u$ の各パラメータについ て, $n, p, u$ は大きいほど処理負荷が小さくなり， $m$ は小さ いほど処理負荷が小さくなる，ということがわかる．理想的 には，処理負荷は小さく，かつパケットロス耐性が良好であ ることが望ましい. しかしながら，第 4.2 節では， $n, p, u$ が大きくなるほどパケットロス耐性が低下することが示さ 
れている. 一方, $m$ は小さいほど良好なパケットロス耐性 を示す．また，第 4.2 節において，署名の誤り訂正符号化 に繰り返し符号を用いた場合, 符号化率は $1 / 2$ 程度で充分 であることも示されている.

一方，同様の単純な方式では，サンプリングを行わないた めに, Audio/Video/Data およびNIT/PMT の合計ビッ トレートは $f(16)=261.024 \mathrm{kbps}$ と見積もることができ る. 署名の生成回数・認証対象の TS の長さを同一条件とし て比較とするため, 想定する単純な方式では, サンプリン グパラメータ $m$ に依存する提案方式の LB 区間 $\left(\frac{n p}{g(m)}\right.$ 秒 $)$ について, 全く同一の LB 区間内のパケットをバッファし, MHVを生成することを考える。 したがって, 想定する単 純な方式では，パケットサンプリング・ハッシュ階層化を 行わないため, 認証対象の TS パケットをバッファするた めに

$$
261.024 \cdot 10^{3} \cdot \frac{n p}{g(m)}=261.024 \cdot \frac{1504 n p}{f(m)} \quad(\text { bits }),(2)
$$

のメモリが必要となる。また, ハッシュ生成処理は一つの LB に対して 1 回のみ行われるため, ハッシュ生成処理は, 1 秒間に $\frac{g(m)}{n p}$ 回と見積もることができる. 想定する単純な 方式は, 提案方式の UB一つに対して署名を一つ生成 (検 証) 寸るため, 署名生成・検証頻度については, 提案方式と 同一と考えることができる.

上記の検討を踏まえ，第 2.1 節にて提示した課題 $(\mathrm{a})$ (d), および提案方式の安全性について, 考察を述べる.ま ず, 課題 $(\mathrm{a}) \sim(\mathrm{d})$ についての考察を以下に述べる.

課題 (a)について：第 4.2 節で示したように，提案方式 は良好なパケットロス耐性を有する。このことより, 無線 伝送路に適した手法であると言え, 課題 (a) を解決するこ とができた。

課題 (b) について: 一般にハッシュ関数は, 入力メッセー ジサイズが $x$ 倍に大きくなったとき, $x$ 倍の演算量が必要 となる. 提案手法は, 想定する単純な手法に比べて $n$ 倍の ハッシュ処理回数が必要となる.これに対して, 提案手法で は, 想定する単純な手法より必要バッファサイズが約 $\frac{f(m)}{261 n}$ 倍小さい. バッファサイズはハッシュ関数の入力メッセー ジサイズに相当するため, 結果として提案手法はハッシュ 処理に関して約 $\frac{261}{f(m)}$ 倍効率が良いと言える.このことよ り, 省バッファ・低処理コストでの送信が可能であり, 課 題 (b) が解決された.

課題 (c) について: 想定した単純な方式と比べたとき, 提 案方式は MHV 生成時のバッファ利用効率が約 $\frac{261 n}{f(m)}$ 倍良 い.また，提案手法では，送信側・受信側ともに MHVの 生成・署名の生成 (検証) など, ほぼ同一の処理が行われる. そのため, 課題 (b) 同様に, 低処理量によって動作すると 言える.これらのことより, 提案方式は, バッファ量や計 算能力が限られる低リソース機器でも充分に動作すること が期待でき, 課題 (c) が解決された.
課題 $(\mathbf{d})$ について： 認証機能に非対応な端末では，受信 時に不要なパケットとして VP は破棄される.したがって， 提案方式が，運用が開始されている ISDB-T 放送受信機に 影響を与えることはないため, 課題 $(\mathrm{d})$ が解決された.

上記に示したように, 提案方式により, 課題 $(\mathrm{a})$ (d) を 解決することができる．また，提案方式を運用する際には， 許容できる処理負荷の範囲内で $n, p, u$ の值を小さくするこ とで，良好なパケットロス耐性を得ることができる．特に $p$ の值は, 図 6 の結果より大きくパケットロス耐性に影響 するため，できる限り小さくすべきである，また，認証対 象パケットのサンプリング頻度 (パラメータ $m$ ) は, 小さく すればするほど想定する単純な手法に比べて処理負荷が軽 減し, 良好なパケットロス耐性を有するようになる。

第 2.2 節に述べた既存手法では，想定した単純な手法と 同様に，すべてのパケットを認証対象とし，ハッシュ・署 名を生成する。したがって, 単純な手法と同様に, パケッ トサンプリングを導入した提案手法と比べて, 処理負荷が 大きいことが明らかである.

次に, 提案方式の安全性についての考察を述べる.

提案方式の安全性について: 提案方式に対して, 以下の攻 撃が予想される.

（1）認証対象パケット以外の改ざん：提案方式はパ ケットサンプリングによって認証対象パケットを決 定する.そのため, 認証対象としたパケットが改ざ んされた場合には，検証処理によって検知可能であ る. 一方, 認証対象以外のパケットが改ざんされた ときに，検知は不可能である．対して，想定する単 純な手法では，すべてのパケットを認証対象とする ために，ほんの一部のパケットが改ざんされたとし ても検知することが可能である.

（2）VP の改ざん：認証対象パケットではなくVP内 部の MHV ・ 符号化署名の断片が改ざんされた場合, 正常に検証することができなくなる．同様に，想定 する単純な手法の場合でも，ハッシュ值および署名 が改ざんされた場合には正常に検証することができ なくなる.

（3） VP の NULL 置換： VPを NULL パケットへ 置換された場合，署名の検証を行うことが不可能と なる，同様に，想定する単純な手法でも，署名とハッ シュを削除された場合，検証することはできない．

（4）不正な検証鍵：受信機内部の検証鍵が，不正な検 証鍵に改ざんされ，さらに署名が不正な秘密鍵で生 成されたものであるとき，不正を検知することがで きない，想定する単純な手法の場合でも同様である.

(1)について，第 3.1 節で述べたように,「パケットが改 ざんされた場合，改ざんを検知可能」もしくは「(認証対象 以外のパケットが改ざんされたため) 改ざんを検知すること 
表 3 実証実験での PC システムスペック

$\mathrm{PC}$ system specification of the experimental demonstration.

\begin{tabular}{c|c}
\hline \hline CPU & Intel Core2Duo E6700 \\
\hline RAM & DDR2 2GB \\
\hline OS & Windows XP Professional SP3 \\
\hline ISDB-T 変調器 & Dektec DTA-115-ISDB(PCI ボード) \\
\hline
\end{tabular}

表 4 実証実験での携帯端末スペック

Mobile phone specification of the experimental demonstration.

\begin{tabular}{c|c}
\hline \hline 端末名 & 京セラ株式会社 MEDIA SKIN (au W52K) \\
\hline CPU & ARM9E \\
\hline チップセット & Qualcomm MSM6550 \\
\hline OS & REX OS + KCP \\
\hline
\end{tabular}

ができなくとも，正常な再生は不可能」と，要件定義して いる. 提案手法において, パラメータ $m$ の值が $m=1$ な ど非常に小さく, メディアのビットレートも低い場合, 認 証対象以外のパケットが改ざんされると,「視聴者がメディ アの内容を読み取れる」という「ほぼ正常」な再生がなさ れる可能性はわずかながら存在する。しかし，こうした状 況は，メディア個々の特性とエンコーダの性質・性能に大 きく依存するため, 特定条件下での最適な $m$ の值が，他の 状況に一般的に当てはまるとは限らない。このため, 定量 的に改ざんを不可能とする範囲で最小の $m$ の值を決定する ことは事実上困難である。ただし，一般的に，受信端末の 性能が許容する範囲，および想定する無線伝送路の安定性 について許容する範囲で， $m$ の值は高いことが望ましい．

(2)について，偽造された MHV，偽造された符号化署 名の断片を格納した VP をストリームへ挿入されたとき， $\mathrm{MHV}$ ・署名の検証時に「ハッシュ検証が不整合」あるいは 「正当な秘密鍵で生成された署名ではない」という結果に なる。このため, メディアの TS パケットが改ざんされて いなくても，不正な放送と判断されてしまう。しかしなが ら，メディア TS パケットの改ざんと VP の改ざんの検知 は，放送ストリームに不正な処理が加えられているという 視点からは等価である。

(3)について, VP が NULL パケットへ置換され，メディ アの TS パケットも不正なコンテンツに改ざんされた場合, 受信機では検証することができない，これに対しては，第 3.3 節で述べているように, ある程度の時間 VP が到来し ない場合に,「署名が存在しない放送である」旨を視聴者に 通知することで，対策が可能である。

(4)について, 提案方式を運用する際に, 受信機が信頼 できる検証鍵を安全に取得できることが必要である。例え ば，検証鍵 (公開鍵) は各放送局から公開鍵証明書の形で取 得すれば，事前に正当性を検証可能である．第 5 節で紹介 する提案方式の実装例では, 実際に携帯電話ネットワーク 上に検証鍵配布サーバを構築し，提案方式を実装した携帯 電話端末に，事前に正当な検証鍵を取得させた。

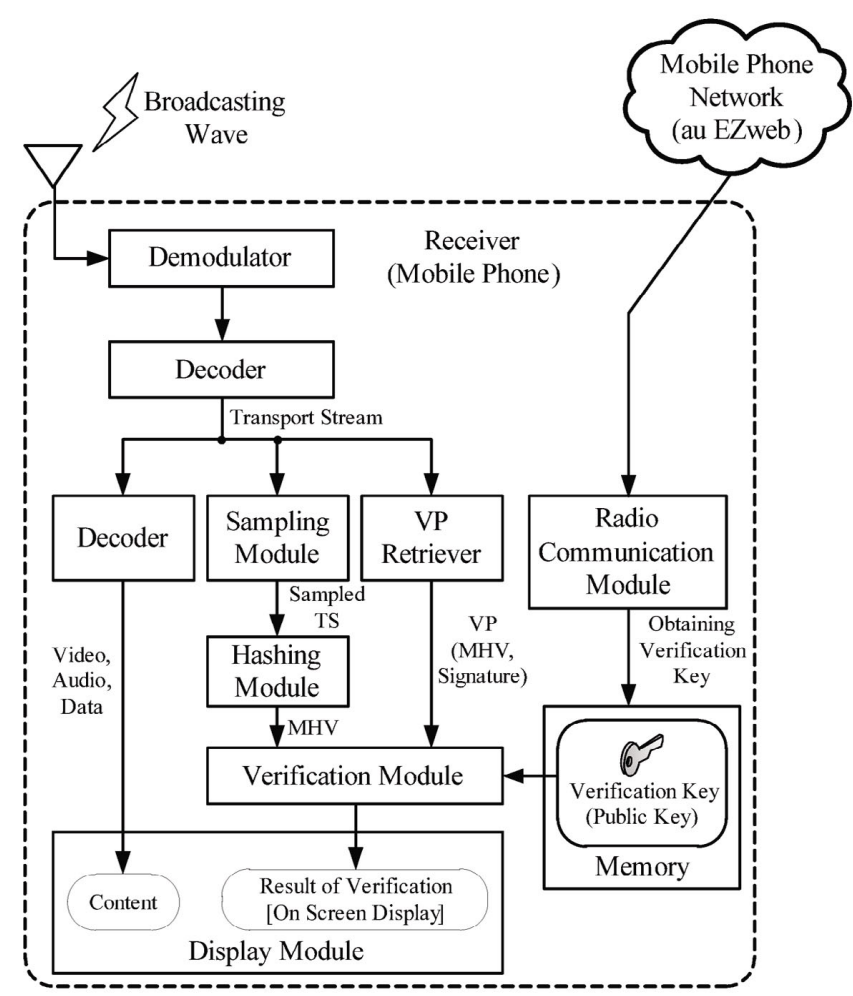

図 9 開発端末のモジュール構成図

Module structure of prototype mobile phone.

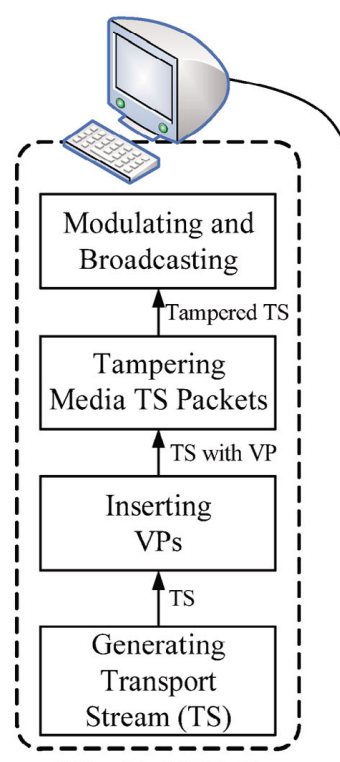

(Weak or Wired)

Broadcasting

Wave

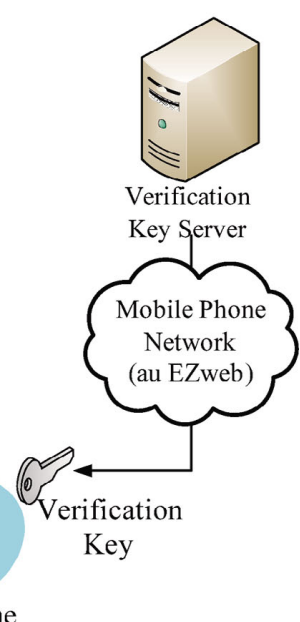

Mobile Phone with Verification Key

PC with ISDB-T

Modulating PCI Board

図 10 実証実験でのシステム構成

System structure of the experimental demonstration.

\section{5. 方 式実装 例}

本節では，提案方式の実装例を紹介する．KDDI 研究所 では，ワンセグローカルスポット放送やエリアポータル放 送への適用を想定し，ワンセグ放送受信機能を有する携帯 電話端末一提案方式を実装し，実証実験を行った。開発し た携帯電話端末 (以下，開発端末と呼ぶ) のモジュール構成 を図 9 に示す。ハッシュ生成モジュール，署名検証モジュー 


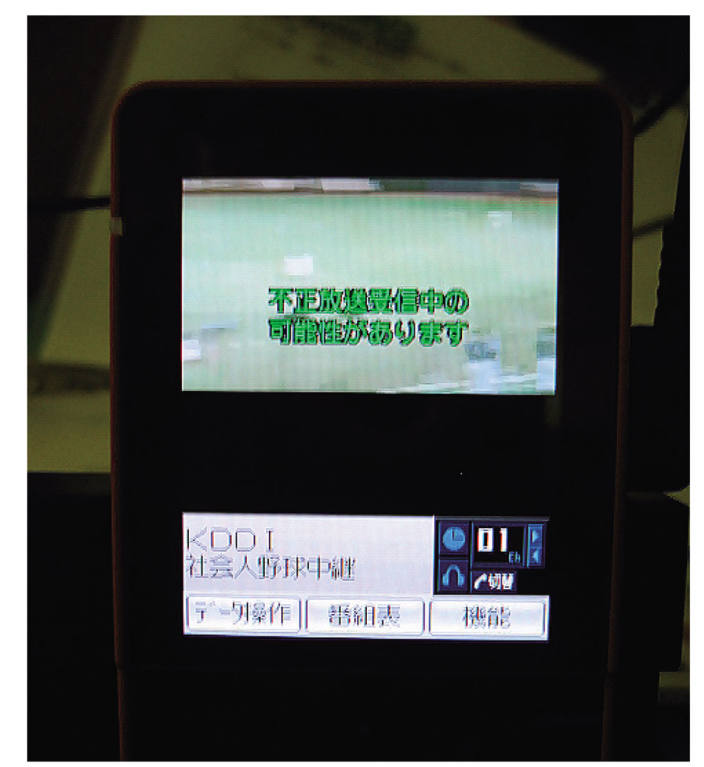

図 11 提案方式を実装した携帯電話端末 (改ざんされた放送の 受信時)

Mobile phone with the proposed scheme (Receiving the tampered 1-Seg stream).

ルなど, 提案方式に関わるモジュール等はソフトウェアで 実装を行った．開発端末では，受信したワンセグ放送波か ら復調・復号されて得られる TSを, 通常の受信端末と同 様にメディア再生用のデコーダへ入力する.この処理と同 時に, TSを, Video/Audio/Data/NIT/PMT 等の TS パ ケットの中で認証対象となるパケットを抽出するサンプリ ングモジュールと，VPを抽出・VPから MHV・署名を抽 出するVP 抽出モジュールへと入力する. サンプリングさ れた TS は連続的にハッシュ生成モジュールへと入力され, $\mathrm{MHV}$ を生成・出力する。検証モジュールでは, VPから取 り出された $\mathrm{MHV}$ ・署名, 認証対象パケットから生成された $\mathrm{MHV}$, 端末内部に保存しておいた検証鍵を用いて, 署名の 検証が行われる．検証結果はワンセグ視聴画面に OSD $(\mathrm{On}$ Screen Display) 表示される.また, 開発端末では, 携帯電 話ネットワーク (au EZweb) を通じて検証鍵をダウンロー ド取得する、検証鍵は開発端末の内部メモリーに保管され, VP 内部に記載される放送局 ID, 検証鍵バージョンに紐づ けられて使用される.

この実証実験のシステム構成を, 図 10, 表 3 および表 4 に示す. 図 10 では, まず, 提案方式に対応した正規のワン セグ放送ストリームを PCにて生成し, TS ファイルに保存 する. 次いで, 同 PCにて保存したTS ファイルの BMLを 改ざんし, 微弱電波あるいはアンテナへの有線接続により 再送信を行い, 開発端末に受信させることで不正放送の検 知を行う。このとき, 送信機材には PC 内部の TS ファイル を ISDB-T 放送として直接変調可能な PCI ボード, Dektec 社製 DTA-115-ISDB ${ }^{20)}$ を用いた。また，実証実験に用 いた PCは, Intel Core2Duo E6700, 2GB RAM, Windows XP の標準的なスペックのものである.さらに，検証 鍵サーバを別途用意し, 携帯電話ネットワーク (au EZweb)
を通じて，開発端末へ検証鍵を前もってダウンロード取得 している. 携帯端末に京セラ株式会社製 MEDIA SKIN(au W52K) を用い，ソフトウェア改修によりストリーム認証 機能を有する端末を開発した。

図 11 に開発した携帯電話端末の表示例を示す. 図 11 で は，改ざんしたワンセグ放送ストリームを受信して，検知 したときの表示を示している. 開発端末では，その他に，正 規放送である場合には「正規放送」の表示，署名の存在し ない放送である場合には「署名のない放送」の表示を行う ように実装している。また，検証鍵を前もってダウンロー ド取得していない場合には，取得を行う旨，検証鍵のバー ジョンが異なる場合には，再取得を行う旨の表示がされる. 本実証実験では，表 2 に示す共通パラメータを用いた。 また, 図 4 に示すVP の構成では, TS Header フィール ドにて，PIDを0x890としVPであることを明示した。ま た，アダプテーションフィールド制御パラメータは $0 \times 1$ と し，アダプテーションフィールドは使用していない. 図 4 に示される VP 特有のフィールドは, セクション形式で保 存している.

このとき, 開発端末上でコマ落ち等が発生することなく， 確実にワンセグ放送ストリームの認証が行えることを確認 している.さらに，ワンセグ受信機能を有する通常の携帯 電話端末では，VPが不要なパケットとして無視され，VP による影響は一切なく正常に再生が可能であることも確認 している.

\section{6. むす び}

本論文では，ワンセグ放送を対象とし，ISDB-T 放送ス トリームのデータの完全性検証に基づいて送信元を認証す る，ストリーム認証方式を提案した．提案方式は，低リソー ス機器でも充分に動作する処理効率と, 無線伝送路に適用 可能なパケットロス耐性を有する．提案方式を利用するこ とにより，例えばワンセグスポット放送，エリアポータル 放送などにおいて，正規の放送局からの放送であることを 保証した，信頼度の高い放送が可能となる．第 1.1 節では， 正規の放送局に成りすました不正放送の一例として「BML 改ざんによるフィッシング詐欺」を挙げた．例えば，この不 正放送が行われたとしても，提案方式を用いることで，TS パケットが改ざんされた不正放送であることを明示的に検 出し，被害を防ぐことができる.

最後に，有益なコメントを頂いた匿名査読者の方々に深 謝する。

\section{〔文献〕}

1) 富士通株式会社: PRESS RELEASE (サービス) 2007 年 3 月 5 日, http://pr.fujitsu.com/jp/news/2007/03/5.html.

2）織田,“エリアを限定したワンセグ放送のサービス実験について,”地域 コミュニティづくりに役立つ ICT ツールに関する研究会, 第 7 回研究 会事例紹介資料, 財団法人地方自治情報センター (2007)

3) ISDB-T(DiBEG): http://www.dibeg.org/.

4）社団法人電波産業会：“地上デジタルテレビジョン放送運用規定 (2.3 版)", ARIB TR-B14 (2005) 
5) R. Gennaro and P. Rohatgi: "How to Sign Digital Streams", CRYPTO '97, LNCS 1294, Springer-Verlag, pp.180-197 (1994)

6) C. K. Wong and S. S. Lam: "Digital Signatures for Flows and Multicasts", IEEE/ACM Trans. Networking, 7, 4, pp.502-513 (1999)

7) R. C. Markle: "A Certified Digital Signature", CRYPTO, LNCS 0435, Springer-Verlag, pp.218-238 (1989)

8) P. Golle and N. Modadugu: "Authenticating Streamed Data in the Presence of Random Packet Loss (Extended Abstract)", NDSS, pp.13-22 (2001)

9) A. Perrig, R. Canetti, D. Tygar and D. Song: "Efficient Authentication and Signing of Multicast Streams over Lossy Channels", IEEE Security and Privacy, pp.56-73 (2000)

10）田中, 中尾, 清本: “ストリーミング転送における効率的なメッセージ認 証方式の検討”, 情処学 CSEC 研資, 101, 214, pp.15-22 (2001)

11）田中, 酒澤, 中尾, 清本: “ストリーミング転送におけるメッセージ認証 システムの設計および実装”, SCIS2002 予稿集, pp.561-566 (2002)

12）上田, 江藤, 川口, 宇田, 重野, 岡田: “IP 電話を想定したリアルタイム 性を持つストリーム認証方式”, 情処学論, 45, 2, pp.605-613 (2004)

13）宇田, 松下: “IP 電話向け音声ストリーム認証方式”, 情処学論, 47, 8 pp.2535-2547 (2006)

14) F. J. MacWilliams and A. J. A. Sloane: "The Theory of ErrorCorrecting Codes", North-Holland Mathematical Library, student revised ed. (1977)

15) B. Schneier: "Applied Cryptography: Protocols, Algorithms, and Source Code in C", Wiley, 2nd edition (1996)

16) 清本, 田中: “モバイル PKI の最適設計について”, 情処学論, $\mathbf{4 7}, 8$, pp.2712-2723 (2006)

17) 羽鳥: “1 セグ放送教科書”，インプレス (2005)

18）栗原，渡辺，清本，田中: “ワンセグ放送を対象としたストリーム認証方 式”, 平 20 年信学総全大, B-15-14 (2008)

19）株式会社 KDDI 研究所：プレスリリース 2007 年 10 月 11 日, http://www.kddilabs.jp/press/detail_68.html.

20）株式会社ヴィレッジアイランド: DTA-115-ISDB, http://www.village-island.com/product/dektec/DTA-115-ISDB/ DTA-115_jpn_2008AUG.pdf.

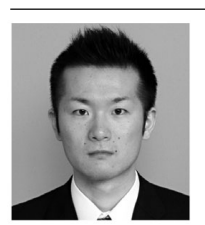

策原占 㧝 2004 年, 東京工業大学工学部情報工 学科卒業. 2006 年, 同大学大学院理工学研究科集積 ステム専攻修了。同年，KDDI 株式会社入社，現在，株 式会社 KDDI 研究所情報セキュリティグループ研究員。 2009 年より, 東京工業大学大学院理工学研究科集積シス テ么専攻博士後期課程に在学. 符号理論, 情報理論, 秘 密分散法の研究等に従事.

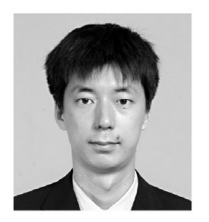

きょもと清本 晋作 2000 年, 筑波大学工学研究科物質工 学専攻博士前期課程修了. 同年, $\operatorname{KDD}($ 株) 入社. 現在, (株)KDDI 研究所情報セキュリティグループ主任研究 員. ストリーム暗号, 暗号プロトコル，モバイルセキュリ ティ，プライバシ保護技術等の研究に従事．2008-2009 年, London 大学 Royal Holloway 校客員研究員. 博士 (工学).

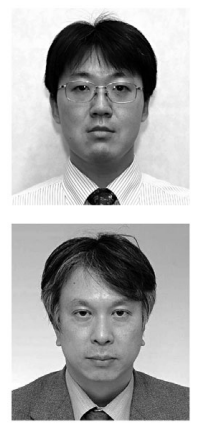

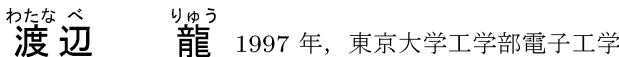
科卒業. 1999 年, 東京大学大学院工学系研究科電子工 学専攻修士課程修了. 同年, $\mathrm{KDD}($ 現 KDDI) 入社. 光 ネットワーク, ネットワークセキュリティ, プライバシー 保護技術等の研究に従事. 現在, 株式会社 KDDI 研究所 情報セキュリティグループ研究主査.

声中か 俊弯袁 1986 年, 大阪大学工学研究科通信工 学専攻博士前期課程修了. 同年, $\operatorname{KDD}($ 株 $)$ 入社. 現在, (株)KDDI 研究所情報セキュリティグループリーダー. 暗号プロトコル，著作権保護，次世代 IDS の研究に従 事. 博士 (工学). 正会員. 